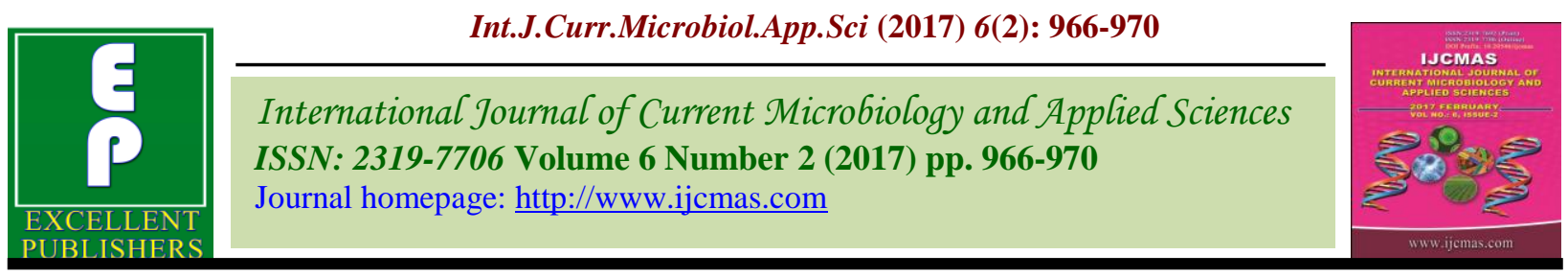

Original Research Article

http://dx.doi.org/10.20546/ijcmas.2017.602.109

\title{
Effect of Organic, Inorganic Source of Nutrients and Azospirillum on Yield and Quality of Turmeric (Curcuma longa $\mathrm{L}$.)
}

\author{
J. C. Jana, S. Datta*, P. T. Bhaisare and A. Thapa \\ Department of Vegetable and Spice Crops, Uttar Banga Krishi Viswavidyalaya \\ Pundibari, Cooch Behar, West Bengal -736165, India \\ *Corresponding author
}

\section{A B S T R A C T}

\begin{tabular}{|l|}
\hline Ke y w o r d s \\
Azospirillum, \\
Inorganic, \\
Growth, Organic, \\
Quality, \\
Turmeric, Yield. \\
\hline Article Info \\
\hline $\begin{array}{l}\text { Accepted: } \\
\text { 20 January } 2017 \\
\text { Available Online: } \\
\text { 10 February } 2017\end{array}$ \\
\hline \hline
\end{tabular}

To study the efficacy of Azospirillum in organic and integrated nutrient management with farmyard manure (FYM) and graded levels of nitrogenous fertilizer on turmeric, an experiment was undertaken at Uttar Banga Krishi Viswavidyalaya, Pundibari, during 2008-09, 2009-10 and 2010-11. The experiment was laid out in randomized block design with three replications. The results revealed that application of $75 \%$ recommended inorganic nitrogen with Azospirillum at $5 \mathrm{~kg} / \mathrm{ha}$ and FYM at $15 \mathrm{t} / \mathrm{ha}$ gave the highest yield of $26.29 \mathrm{t} / \mathrm{ha}$ as against $22.96 \mathrm{t} / \mathrm{ha}$ in the control of recommended dose of fertilizers at the rate of 80:80:120 kg N, $\mathrm{P}_{2} \mathrm{O}_{5}$ and $\mathrm{K}_{2} \mathrm{O}$ per hectare. It was followed by the combined application of $50 \%$ recommended inorganic nitrogen with Azospirillum at $5 \mathrm{~kg} / \mathrm{ha}$ and FYM at $15 \mathrm{t} /$ ha with a yield of $25.8 \mathrm{t} / \mathrm{ha}$ and then $100 \%$ recommended in organic nitrogen with Azospirillum at 5kg/ha and FYM at $15 \mathrm{t} / \mathrm{ha}$ with a yield of $25.81 \mathrm{t} / \mathrm{ha}$. The lowest yield of $18.36 \mathrm{t} / \mathrm{ha}$ was recorded in the treatment of sole application of FYM at $15 \mathrm{t} / \mathrm{ha}$. The lowest dry recovery of $25.6 \%$ and curcumin content of $4.95 \%$ were recorded in control treatment with the application of only recommended dose fertilizers while the highest dry recovery of $26.87 \%$ was recorded with integrated nutrient management with application of $75 \%$ recommended inorganic nitrogen with Azospirillum at $5 \mathrm{~kg} / \mathrm{ha}$ and FYM at 15 t/ha and curcumin content of $5.11 \%$ was recorded in organic nutrient management with Azospirillum at $5 \mathrm{~kg} / \mathrm{ha}$ and FYM at $30 \mathrm{t} / \mathrm{ha}$.

\section{Introduction}

Turmeric (Curcuma longa L.) is an important spice crops in the world. India is the largest producer and exporter of this crop. It is extensively used in culinary application, cosmetic, pharmaceutical and dyeing industries. Indian turmeric has the high demand in the world market. In order to meet the export and internal demands of turmeric, production has to be increased. For its long crop duration, rhizomatous nature and high productivity it requires heavy input of fertilizers. Continuous uses of inorganic chemical fertilizers negatively affect the soil health and crop quality and pollute under ground water. To solve the above problem it is essential to reduce the indiscriminate use of inorganic chemical fertilizer and simultaneously use of different bio-fertilizers and organic nutrient sources. Mishra and Gopalkrishnan (2006) emphasized on organic production of turmeric keeping in view the increasing global demand for organic products. Azospirillum is known to fix a substantial amount of atmospheric nitrogen and supplies to the crop, enhances 
the fertilizer use efficiency, soil fertility status and ensures partial saving of nitrogenous fertilizer. The ability of the Azospirillum to proliferate in the rhizosphere of crop suggests its ability to improve the nutrient availability to the plants and can supplement the expensive inorganic and organic fertilizers. Therefore, the present investigation was carried out to assess the efficacy of organic, inorganic source of nutrients and Azospirillum on yield and quality of turmeric in terai agroclimatic zone of West Bengal.

\section{Materials and Methods}

The experiment was conducted to assess the efficacy of organic, inorganic source of nutrients and Azospirillum on yield and quality of turmeric at Uttar Banga Krishi Viswavidyalaya, Pundibari during 2008-09, 2009-10 and 2010-11 with the variety Rajendra Sonia. The experiment was laid out in randomized bock design with three replications. The soil was sandy loam and

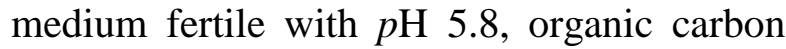
$1.14 \%$, available nitrogen $189.28 \mathrm{~kg} / \mathrm{ha}$, available phosphorus $36.47 \mathrm{~kg} / \mathrm{ha}$ and available potassium $75.78 \mathrm{~kg} / \mathrm{ha}$. Eight different treatments were studied in this experiment viz. $\mathrm{T}_{1}: 100 \%$ inorganic nitrogen + Azospirillum $10 \mathrm{~kg} / \mathrm{ha}+\mathrm{FYM} 10 \mathrm{t} / \mathrm{ha}, \mathrm{T}_{2}$ : $75 \%$ inorganic nitrogen + Azospirillum 10 $\mathrm{kg} / \mathrm{ha}+\mathrm{FYM} 10 \mathrm{t} / \mathrm{ha}, \mathrm{T}_{3}: 50 \%$ inorganic nitrogen + Azospirillum $10 \mathrm{~kg} / \mathrm{ha}+\mathrm{FYM} 10$ t/ha, $\mathrm{T}_{4}$ : Azospirillum $10 \mathrm{~kg} / \mathrm{ha}+\mathrm{FYM} 10$ t/ha, $\mathrm{T}_{5}:$ Azospirillum $10 \mathrm{~kg} / \mathrm{ha}+\mathrm{FYM} 20$ t/ha, T 6 : 10 t/ha FYM, T $7: 20$ t/ha FYM and $\mathrm{T}_{8}$ : recommended dose of inorganic nitrogen $80 \mathrm{~kg} / \mathrm{ha}$. Phosphorus $80 \mathrm{~kg} / \mathrm{ha}$ and potash $120 \mathrm{~kg} / \mathrm{ha}$ were applied uniformly to each treatment. Seed rhizomes were sown during $3^{\text {rd }}$ week of April in plots of $3.0 \mathrm{~m} \mathrm{x} 1.0 \mathrm{~m}$ size with spacing of $30 \mathrm{~cm} \times 20 \mathrm{~cm}$. Full dose of FYM, Azospirillum, phosphorus and $50 \%$ potassium were applied as basal during the time of final land preparation. $50 \%$ inorganic nitrogen was top dressed at 45 days and remaining $50 \%$ inorganic nitrogen and $50 \%$ potassium were top dressed at 90 days after planting. Mulching with paddy straw 20 t/ha and other intercultural operations were practiced uniformly to all treatments. Harvesting was done during the month of the February. Observations of fresh rhizome yield, dry recovery and curcumin content were recorded. Observations were recorded on ten plants selected randomly in each plot. Statistical analysis was carried out on method as suggested by Gomez and Gomez (1984). The economical parameters, like net monetary returns and benefit: cost ratios were worked out by using the prevailing market price of inputs and outputs in the locality.

\section{Results and Discussion}

Pooled data presented in table 1 revealed that the highest fresh rhizome yield per plant $(236.70 \mathrm{~g})$, per plot $(9.90 \mathrm{~kg})$ and per hector (26.29 ton) were obtained with the treatment of $75 \%$ inorganic nitrogen + Azospirillum 10 $\mathrm{kg} / \mathrm{ha}+\mathrm{FYM} 10 \mathrm{t} / \mathrm{ha}$ whereas the lowest fresh rhizome yield was recorded in the treatment of FYM $10 \mathrm{t} / \mathrm{ha}$. Higher rhizome yield by the treatment $\mathrm{T}_{2}$ might be due to higher availability of mineral nitrogen as well as higher organic carbon present in FYM. The lowest yield with 10 t/ha FYM may be due to shortage of readily available nitrogen at the initial active growth stage which might have delayed plant growth at early stages. Again presence of Azospirillum might have enhanced the activity of growth promoting substances, all have jointly promoted better nutrient up take and subsequently increased the rhizome yield of turmeric (Table 2).

Increased dose of FYM has increased the rhizome yield, dry recovery and curcumin content in rhizome. 
Table.1 Effect of organic, inorganic source of nutrients and Azospirillum on yield of turmeric variety Rajendra Sonia

Treatment

\begin{tabular}{|c|c|c|c|c|c|c|c|c|c|c|c|c|}
\hline $\mathrm{T}_{1}: 100 \% \mathrm{~N}+$ Azospirillum $+\mathrm{FYM}$ & 159.2 & 164.9 & 346.2 & 223.43 & 9.2 & 9.5 & 9.63 & 9.44 & 24.5 & 25.8 & 27.14 & 25.81 \\
\hline $\mathrm{T}_{4}:$ Azospirillum $+\mathrm{FYM}$ & 129.8 & 122.6 & 236.7 & 163.03 & 7.0 & 7.8 & 7.87 & 7.56 & 18.7 & 19.4 & 23.32 & 20.47 \\
\hline $\mathrm{T}_{5}:$ Azospirillum $+2 \mathrm{FYM}$ & 138.6 & 149.7 & 241.9 & 176.73 & 7.8 & 8.4 & 8.63 & 8.28 & 20.8 & 21.0 & 25.94 & 22.58 \\
\hline $\mathrm{T}_{6}: \mathrm{FYM}$ & 115.4 & 116.2 & 216.2 & 149.37 & 6.4 & 7.0 & 7.07 & 6.82 & 17.1 & 17.5 & 20.48 & 18.36 \\
\hline $\mathrm{T}_{7}: 2 \mathrm{FYM}$ & 130.1 & 133.8 & 225.2 & 163.03 & 7.6 & 8.1 & 8.03 & 7.91 & 20.3 & 20.3 & 22.25 & 20.95 \\
\hline $\mathrm{T}_{8}$ :Recommended Fertilizer Dose & 160.3 & 148.2 & 224.7 & 183.07 & 8.9 & 8.7 & 8.83 & 8.81 & 23.7 & 21.8 & 23.37 & 22.96 \\
\hline $\mathrm{CD}(5 \%)$ & 24.4 & 14.1 & 20.9 & - & 1.3 & 0.9 & 0.4 & - & 2.6 & 2.1 & 1.15 & - \\
\hline
\end{tabular}

Recommended dose of fertilizer- 80: 80: $120 \mathrm{~kg} \mathrm{~N}, \mathrm{P}_{2} \mathrm{O}_{5}$ and $\mathrm{K}_{2} \mathrm{O}$ per hectare

Table.2 Effect of organic, inorganic source of nutrients and Azospirillum on quality of turmeric variety Rajendra Sonia

\begin{tabular}{lcccccccc}
\hline Treatment & \multicolumn{3}{c}{ Drying percentage } & \multicolumn{3}{c}{ Curcumin content (\%) } \\
\cline { 2 - 9 } & $2008-09$ & $2009-10$ & $2010-11$ & Mean & $2008-09$ & $2009-10$ & $2010-11$ & Mean \\
\hline $\mathrm{T}_{1}:$ 100\% N+Azospirillum + FYM & 26.1 & 26.8 & 25.9 & 26.27 & 4.98 & 5.01 & 5.06 & 5.02 \\
$\mathrm{~T}_{2}: 75 \%$ N+ Azospirillum + FYM & 26.5 & 27.5 & 26.6 & 26.87 & 5.05 & 5.11 & 5.12 & 5.09 \\
$\mathrm{~T}_{3}:$ 50\% N+ Azospirillum + FYM & 25.6 & 25.9 & 25.5 & 25.67 & 5.04 & 5.01 & 5.03 & 5.03 \\
$\mathrm{~T}_{4}:$ Azospirillum + FYM & 26.2 & 27.1 & 26.4 & 26.57 & 5.01 & 5.05 & 5.05 & 5.04 \\
$\mathrm{~T}_{5}:$ Azospirillum + 2 FYM & 25.5 & 27.2 & 25.7 & 26.13 & 5.03 & 5.22 & 5.08 & 5.11 \\
$\mathrm{~T}_{6}:$ FYM & 25.9 & 26.3 & 25.3 & 25.83 & 4.85 & 5.01 & 5.02 & 4.96 \\
$\mathrm{~T}_{7}$ : FYM & 26.2 & 26.7 & 26.5 & 26.47 & 5.00 & 5.14 & 5.04 & 5.06 \\
$\mathrm{~T}_{8}:$ Recommended Fertilizer Dose & 25.8 & 26.2 & 24.8 & 25.60 & 4.82 & 5.02 & 5.02 & 4.95 \\
\hline
\end{tabular}



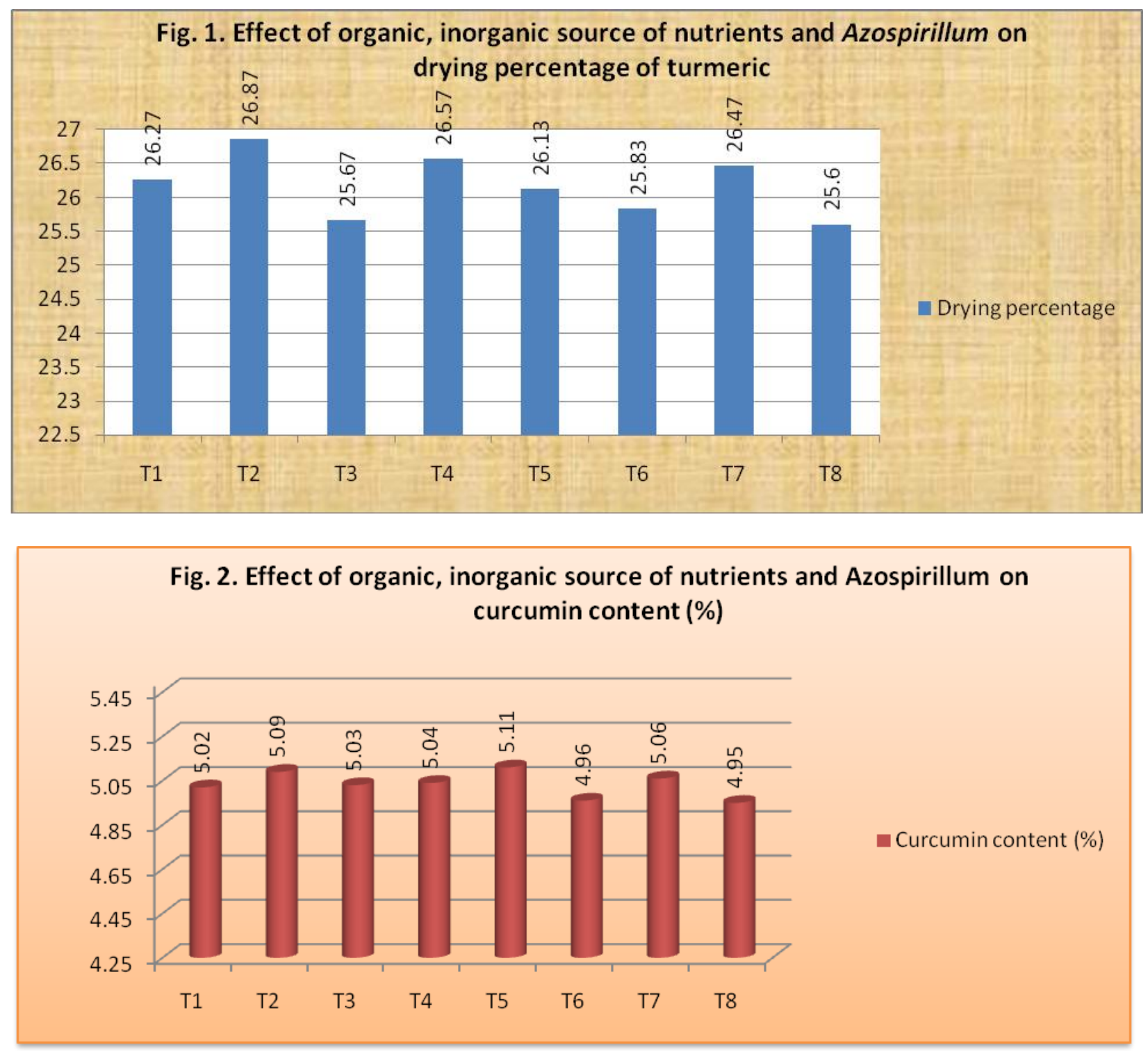

FYM combined with Azospirillum further, increased in rhizome yield, dry recovery and curcumin content in rhizome. Azospirillum and FYM in enhancing yield of ginger (Dash et al., 2008), black pepper (Kandiannan et al., 2000) and coriander (Malhotra et al., 2006) were reported earlier.

Curcumin content which increases the turmeric quality was higher in all the treatments where Azospirillum were applied which shows curcumin enhancement with the use of biofertilizer. This is in conformation with the earlier works Velmurgan and Chezhian (2005) and Upadhayay and Mishra (1999) on turmeric.

The combined application of $75 \%$ inorganic nitrogen + Azospirillum $10 \mathrm{~kg} / \mathrm{ha}+$ FYM 10 $\mathrm{t} /$ ha recorded the maximum curcumin content $(5.09 \%)$ and drying recovery $(26.87 \%)$ compared to rest of the treatments (Fig. 1). This may be due to the availability of more quantity of nutrients which could have promoted curcumin synthesis in plant synthesis (Fig. 2). 
In conclusion, considering all the above aspects together two types of recommendations can be given for two situations. In one situation where $75 \%$ inorganic nitrogen + Azospirillum $10 \mathrm{~kg} / \mathrm{ha}+$ FYM 10 t/ha can be recommended to obtain the highest fresh turmeric yield with high curcumin content. Combination of all organic, inorganic nitrogen and nitrogenous biofertilizer saved use of $25 \%$ inorganic nitrogen. In case of $100 \%$ organic farming, farmers need to use Azospirillum $10 \mathrm{~kg} / \mathrm{ha}$ and double dose of FYM i. e., 20 t/ha to obtain sustainable yield.

\section{References}

Dash, D.K., Mishra, N.C. and Sahoo, B.K. 2008. Influence of nitrogen, Azospirillum sp and farn yard manure on yield, rhizome rot and quality of ginger (Zingiber officinale Rosc.). $J$. Spices Aromatic Crops, 15:115-117.

Gomez, K.A. and Gomez A.A. 1984. Statistical Procedures for Agricultural Research ( $2^{\text {nd }}$ Ed.). A Willey-Inter Science Publication (John Wiley and sons), New York., pp. 20-30.

Kandiannam, K., Sivarman, K., Anandaraj,
M. and Krishnamurthy, K.S. 2000. Growth and nutrient content of black pepper (Piper nigrum L.) cuttings as influenced by inoculation with biofertilizers. J. Spices, Aromatic Crops, 9:145-147.

Malhotra, S.K., Vashishtha, B.B. and Appa Rao, V.V. 2006. Influence of nitrogen, Azospirillum sp and farn yard manure on growth, yield and incidence of stem gall disease in coriander (Coriendrum sativum L.). J. Spices Aromatic Crops, 15: 115-117.

Mishra, N.C. and Gopalkrishnan, P.C. 2006. Production of organic turmeric and ginger in Orissa. Spice India, 19(4): 2123.

Upadhayay, D.C. and Mishra, R.S. 1999. Nutritional study of turmeric Cv. Roma under agroclimatic condition of eastern Uttar Pradesh. Progressive Hort., 31(3/4): 214-218.

Velmurgan, M. and Chezhian, N. 2005. Effect of organic manure and biofertilizers on growth, yield and quality of turmeric Cv. BSR-2. South Indian Hort., 53(1-6): 392-396.

\section{How to cite this article:}

Jana, J.C., S. Datta, P.T. Bhaisare and Thapa, A. 2017. Effect of Organic, Inorganic Source of Nutrients and Azospirillum on Yield and Quality of Turmeric (Curcuma longa L.). Int.J.Curr.Microbiol.App.Sci. 6(2): 966-970. doi: http://dx.doi.org/10.20546/ijcmas.2017.602.109 